\title{
LIVEABLE CITY FROM AN ECONOMIC PERSPECTIVE
}

\author{
Antonescu Daniela \\ Institute of National Economy, Romanian Academy (ROMANIA) \\ daniela.antonescu25 [at] gmail.com
}

\begin{abstract}
The purpose of this article is to provide an overall image of what a liveable city is. Starting from the theoretical aspects presented in the first part of this work, and ending up with the practical ones, an attempt was made to provide an answer to the following question: Why are some cities more attractive than others and what criteria should be fulfilled for the life of a city's inhabitants to be considered qualitative, and that city to be deemed liveable. For a city to be liveable, it is bound to fulfil several conditions, the most important ones being related to economy, environment, infrastructure (healthcare, transport, education, etc.), but also to aesthetics and culture, ambient, ways of spending leisure time, safety of life, vicinity, etc.

Even though there is no generally accepted concept of a liveable city, a series of methodologies recognised globally provide an assessment of this very aspect (many of them sharing the same elements). In this article, by means of the Liveability indices, cities are classified into several categories. The cities listed in one category are shown to be present in almost all the other categories, on positions that are similar. Hence, the city of Tokyo can be found in five out of six categories proposed by the international organisations which elaborated such methodologies, along with the City of London (in four out of six categories) and with New York City (in four out of six categories) etc. In Romania, the cities that might be classified as liveable are: Bucharest, Cluj-Napoca, Timisoara, Brasov, Constanța and Sibiu. The Capital City of Romania, i.e. Bucharest, is ranked the $28^{\text {th }}$ in a List of European Capital Cities, being outranked by Cities like Sofia, Lisbon or Budapest, which means it still does not fulfil many of the criteria for a liveable city.
\end{abstract}

Keywords: Liveability, sustainable development, liveable city, urban economy

\section{INTRODUCTION}

The process of world urbanisation is obvious, according to international reports (prepared by the World Bank, by the European Commission, etc.) which show a significant increase, in the last three decades, of the urban population: from $42.93 \%$ in 1990 , to $53.86 \%$ in $2015^{1}$ (3.943 billion inhabitants). According to specialists, the growth trend will continue, so that by 2030 , approximately $70 \%$ of the world population will live in cities.

\footnotetext{
${ }^{1}$ http://data.worldbank.org/indicator/SP.URB.TOTL.IN.ZS [10.05.2017].
} 
Romania is also part of this active urbanisation phenomenon, the urban population reaching approximately $54.56 \%$ in 2015 (10.82 million inhabitants), yet with a much less aggressive growth trend registered in the reference period (in 1990, the percentage was $53.22 \%$ ). Despite this trend, for the capital-city - Bucharest, the trend are to diminishing the total resident population $(-2.38 \%)$, for the period $2012-$ 2016, from 2.158 million inhabitants to 2.107 million.

In the European Union, this percentage exceeds the global value, reaching (in 2015) the value of $74.8 \%$ ( 381.23 million inhabitants) from the total population, the growth trend being obvious in comparison with 1990 , when the percentage was $70.7 \%$.

This growth trend of the urban population, and particularly from large cities, represents a phenomenon that mankind has undergone for some time, and which entails a particular level as regards the quality of life and the individual well-being.

At the same time, the acute urbanisation phenomenon has also given rise to the enhanced role that cities play from an economic perspective, as they are considered actual economic growth engines, which contribute to an increased mobility of manpower and to (financial, technological, innovative and alike) capital. It is wellknown that cities hold over $80 \%$ of the Global Gross Domestic product (GDP) (McKinsey Global Institute).

Practically, in a globalised world, cities become economic competitors, joining the increased competitive struggle, aiming at boosting their attractiveness to inhabitants and companies, no matter the means. But the attractiveness of cities is closely related to the concept of 'liveability', which thus becomes a fundamental characteristic of the worldwide competitive struggle to attract resources of any kind, as this is known to contribute to the local economic growth, economic resilience, social \& cultural innovation, improved standard of living. Moreover, competition between cities is regarded as a strategic competition between nations, turning cities into the epicentre of economic, social, cultural advantage, etc.

For this reason, an increasing growth has been ascertained in recent years in the interest for the liveability of cities, both from the part of the academic environment, and from that of the policy-makers, which on the one hand, has determined the promotion of certain methodologies of assessment of the liveability level, and on the other hand, the launch of some proper urban policies, meant to contribute to the growth of this significant quality of present modern cities.

The methodologies launched at international level are based on the elaboration of certain indices aiming at assessing the relative position that cities occupy, function of the obtained values. The indices are built based on certain indicators which measure the multi-dimensional aspects of human well-being, namely: personal mobility, security, environment, urban aesthetics, good governance, cultural actions etc. Further on, there is a presentation of the means of assessment of a city's liveability level, along with the results obtained after the conduct of certain international surveys and research activities.

\section{DEFINING 'LIVEABILITY' - RELATED LITERATURE}

There is no generally accepted form/formula for the concept of liveability, yet it has several qualitative and quantitative facets. This concept depends on two other concepts, which render its definition possible: quality of life and well-being. 
Frequently used in the ' 80 s and ' 90 s in the USA, this concept was initially approached in close connection with the urban community that it would define / characterise, on the background of the issues generated by city extension and growing dependency upon vehicles (cars). The surveys and analyses conducted with respect to the concept of liveability attempted to identify the elements underlying competitiveness at city level, trying to inform the authorities regarding living conditions, so as to attract human and financial/entrepreneurial capital. In his study entitled 'The Cities and the Creative Class', ${ }^{2}$ Richard Florida, a renowned economist, supported the idea that cities need a 'people climate', namely an environment where the city inhabitants can feel comfortable and where they can fulfil their life aspirations.

From a social perspective, the concept of liveability has tried to bring equity in the limelight, while from an economic viewpoint, its purpose was to contribute to the making of beneficial policies for all inhabitants, and particularly for those who are underprivileged.

The use of the concept of liveability has called for the recognition of other concepts, such as the concepts of sustainable-city, smart-city, global-city, perfect-city, fastestcity, which are strongly interdependent (but which cannot be entirely overlapped). Often, the concept of liveability is considered to represent one of the fundamental elements of sustainability (along with economic performances, environmental protection and good governance).

In the period after 1990, the interventions (discussions) with respect to the liveability of cities have become more and more frequent, because the inhabitants of urban areas have become aware of the fact that, besides the advantages related to economy, infrastructure and alike, a city should first and foremost be a place for them to live, to raise their children and to age in a pleasant way. As a matter of fact, most of the definitions of this concept focus on a certain standard for the quality of life, a standard aimed at by all cities and by their inhabitants.

In order to provide a definition for this concept, several approaches are necessary, but the majority of those who analyse it agree with the idea that, for a city to be liveable, it does not depend very much on the statute of the country to which it belongs (developed or less developed country), but this characteristic rather refers to the attractiveness of the city, given by social activities, economic solidity, entrepreneurial environment etc. It becomes obvious that the concept of city liveability is difficult to measure, despite the acknowledgment of certain joint elements: cost of living, quality of life, happiness, well-being etc. From this perspective, the concept of liveable city should fulfil three main functions, which finally provide the prosperity of the entire city (cf. Figure 1 ):

1. Economic: high productive rate, low costs, significant income and economic results;

2. Material and functional (proper urban infrastructure and services; clean environment);

3. Technical and apolitical (good governance, experts, specialists, townplanners, economists, architects, etc. available for coming up with

\footnotetext{
${ }^{2}$ Florida R. (2002), The Cities and Creative Class. Available at: http://creativeclass.com/rfcgdb/articles/4\%20Cities\%20and\%20the $\% 20$ Creative $\% 20$ Class.pdf [10.05.2017].
} 
development strategies in line with the global trends and with the local requirements).

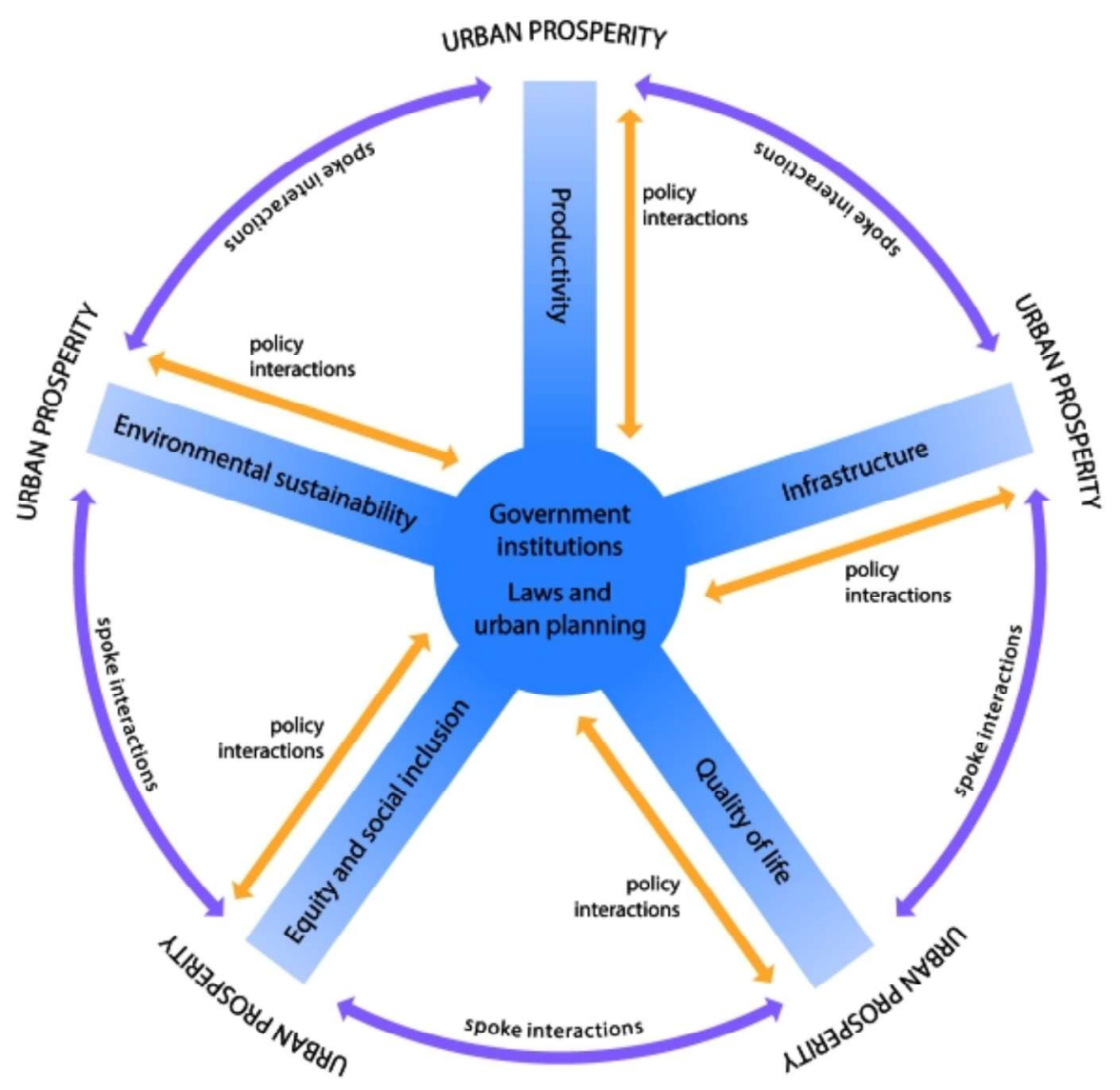

Figure 1: Urban Prosperity

Source: https://www.siemens.com/innovation/en/home/pictures-of-the-

future/infrastructure-and-finance/livable-and-sustainable-cities-facts-and-forecastseconomic-imbalances-are-growing-in-cities-worldwide.html [10.05.2017].

\section{MEANS OF ASSESSING THE LIVEABILITY INDEX. INTERNATIONAL RANKINGS}

For assessing an economic or social phenomenon of high complexity, an index is usually elaborated to provide a synthetic expression of such phenomenon, based upon several indicators.

As for the measurement of the liveability level, the literature specialised in this field provides a series of Indices, calculated by various international bodies based on several well-known methodologies, indices which are used at specific moments (annually, as a rule) in to order to perform the liveability rankings of cities around the world, based on a rigorous selection and on certain official statistical data. A synthetic presentation of such indices is provided below: 


\subsection{The Global Power City Index}

The Global Power City Index, ${ }^{3}$ elaborated by Mori Memorial Foundation, known as the 'Mori Index' (MI), provides the ranking of cities at global scale, considering their 'magnetism', which means their ability to attract creative individuals and companies from every continent, and to use their assets in domains such as economic \& social security and environmental protection. The Mori Index provides a general assessment of the power held by 40 leading cities worldwide, based on six main functions: economic, research and development, cultural interaction, environment and accessibility, considered to represent the driving force of cities. The performed analyses envisage the global players which lead the urban activities carried out in their cities, namely the Manager, the Researcher, the Artist, the Visitor and the Resident (cf. Table 1).

\begin{tabular}{|c|c|c|}
\hline Function & Indicator Groups & Indicators \\
\hline \multirow[t]{7}{*}{ Economic } & Market Size & \multirow{7}{*}{ 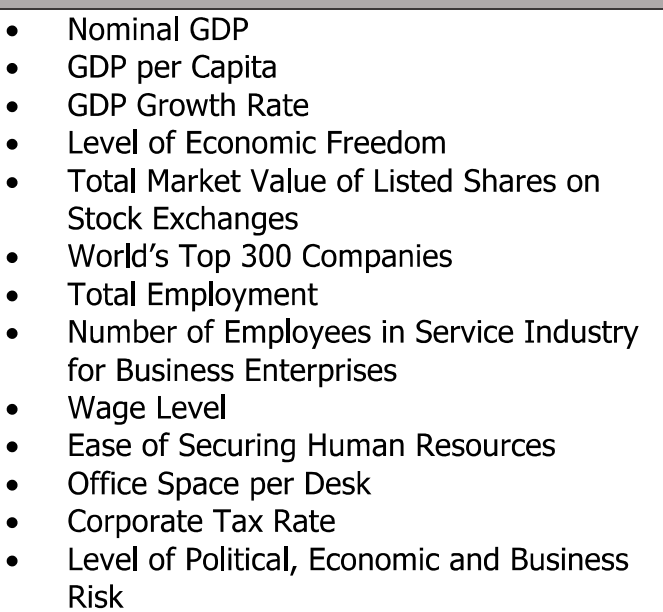 } \\
\hline & Market & \\
\hline & Attractiveness & \\
\hline & Economic Vitality & \\
\hline & Human Capital & \\
\hline & $\begin{array}{l}\text { Business } \\
\text { Environment }\end{array}$ & \\
\hline & $\begin{array}{l}\text { Ease of Doing } \\
\text { Business }\end{array}$ & \\
\hline \multirow{3}{*}{$\begin{array}{l}\text { Research and } \\
\text { Development }\end{array}$} & Academic Resources & \multirow{3}{*}{$\begin{array}{ll}\text { - } & \text { Number of Researchers } \\
\text { - } & \text { World's Top } 200 \text { Universities } \\
\text { - } & \text { Academic Performance in Mathematics and } \\
\text { - } & \text { Science } \\
\text { - } & \text { Readiness for Accepting Researchers } \\
\text { - } & \text { Number of Registered Industrial Property } \\
\text { - } & \text { Rights (Patents) } \\
\text { Number of Winners of Highly-Reputed } \\
\text { Prizes (Science and Technology-Related } \\
\text { Fields) } \\
\text { Interaction Opportunities between } \\
\text { Researchers }\end{array}$} \\
\hline & $\begin{array}{l}\text { Research } \\
\text { Background }\end{array}$ & \\
\hline & $\begin{array}{l}\text { Research } \\
\text { Achievement }\end{array}$ & \\
\hline
\end{tabular}

Table 1: Economic and Research Function - the Main Indicators

Source: http://mori-m-foundation.or.jp/pdf/GPCI2016_en.pdf [10.05.2017].

${ }^{3}$ http://mori-m-foundation.or.jp/english/ius2/gpci2/index.shtml [10.05.2017]. 
Given the Mori Index values, developed based on economic and of research and development indicators, the global ranking of cities (the top 10 cities of the world) is given below ( $c f$. Table 2).

\begin{tabular}{|c|c|c|c|c|c|}
\hline & Economy Rankings & MI & & R\&D Rankings & MI \\
\hline 1. & Tokyo & 311.0 & 1. & New York & 215.8 \\
\hline 2. & London & 307.5 & 2. & Tokyo & 162.9 \\
\hline 3. & New York & 298.7 & 3. & London & 162.4 \\
\hline 4. & Beijing & 297.5 & 4. & Los Angeles & 145.7 \\
\hline 5. & Hong Kong & 278.1 & 5. & Seoul & 122.7 \\
\hline 6. & Singapore & 261.3 & 6. & Boston & 118.4 \\
\hline 7. & Shanghai & 261.1 & 7. & Singapore & 112.0 \\
\hline 8. & Zurich & 254.6 & 8. & Paris & 111.9 \\
\hline 9. & Seoul & 239.8 & 9. & San Francisco & 111.0 \\
\hline 10. & Sydney & 230.4 & 10. & Chicago & 99.6 \\
\hline
\end{tabular}

Table 2: Economic and Research Function - Index Ranking for 2016

Source: http://mori-m-foundation.or.jp/pdf/GPCI2016_en.pdf [10.05.2017].

\subsection{The Global Cities Index}

The Global Cities Index (GCI) is proposed and calculated by Foreign Policy Magazine, The Chicago Council on Global Affairs, A. T. Kearney (2010), being known as the Foreign Policy Index.

This index assesses the current performance of cities based on 13 indicators from the following domains: economic (25\%), individual well-being $(25 \%)$, governance $(25 \%)$ and innovation (25\%), providing a follow-up of the evolution of 125 cities worldwide. From an economic perspective, the indicators subject to analysis are the GDP and the long-term investments. They are supplemented by the following innovative indicators: patent, private investments and business incubators. This index is calculated in two ways: the Global Cities Index and the Global Cities Outlook, whose values and rankings are presented below (cf. Table 3 ).

\begin{tabular}{|c|c|c|c|c|c|}
\hline & City & GCI & & City & GCI \\
\hline 1. & London & 52.7 & 1. & San Francisco & 70.6 \\
\hline 2. & New York & 62.5 & 2. & New York & 70.4 \\
\hline 3. & Paris & 54.5 & 3. & Boston & 67.8 \\
\hline 4. & Tokyo & 46.7 & 4. & London & 67.1 \\
\hline 5. & Hong Kong & 44.2 & 5. & Huston & 61.0 \\
\hline 6. & Los Angeles & 38.2 & 6. & Atlanta & 61.0 \\
\hline 7. & Chicago & 38.0 & 7. & Stockholm & 60.6 \\
\hline 8. & Singapore & 37.9 & 8. & Amsterdam & 60.4 \\
\hline 9. & Beijing & 36.0 & 9. & Munich & 60.1 \\
\hline 10 & Washington DC & 34.7 & 10. & Zurich & 59.4 \\
\hline
\end{tabular}

Table 3: Global Cities Index and Global Cities Outlook for 2016

Source:

https://www.atkearney.com/documents/10192/8178456/Global+Cities+2016.pdf/8139cd44c760-4a93-ad7d-11c5d347451a [10.05.2017].

An important position in the above-mentioned ranking is held by the Global Elite, namely the cities holding the highest ranking in both classifications (i.e. the Global Cities Index and the Global Cities Outlook). Usually, these cities have an average population of 8.8 million inhabitants and a total GDP of USD 7.3 trillion. 
Moreover, in the aforementioned reports, two other categories of cities are mentioned, namely the 'Perfect Cities' and the 'Fastest Cities'. An example of perfect city is Genoa, while Sydney, Melbourne and Brussels are examples of fastest cities.

\subsection{The Knight Frank Index}

The Global Cities Index, proposed by Frank Knight ${ }^{4}$ (Citi Private Bank), known as the 'Knight Frank Index'. In his assessment report, Knight proposes an approach mainly focused on economic aspects and on the human perception of the degree of liveability (the so-called 'people-centric' approach). In other words, the driving force of urban development consists of finance, aerospace industry, consumer and/or processed goods, and the most important asset of all, educated and creative manpower. Consequently, the real estate activities become more and more attractive against the background of building an environment which attracts and preserves its inhabitants.

\subsection{The Global City Competitiveness Index}

The Global City Competitiveness Index, proposed by Economist Intelligence Unit (EIU) and by Citi-Group, known as the 'EIU-Competitiveness Index'.

In the first stage of its elaboration, this index envisaged the geographical / spatial characteristics of cities, grouped into six fields ( $25 \%$ of the Index), as well as the specific characteristics, grouped into five major domains: stability, health, culture, environment, education and infrastructure ( $75 \%$ of the Index).

Afterwards, other domains were also included, such as: shape of cities (expansion, extent, green space size), geographical location of cities (natural characteristics, isolation or connectivity), culture-related aspects and pollution level. Such space features are assessed in relation to 70 cities, by means of the Liveability Index, based on the following main selection criteria: population size, geographical distribution, as well as on the fact that all residents benefit from the city's natural resources, but suffer from air pollution. The top 10 city ranking performed on a global scale, elaborated based upon the Liveability Index value, is presented in Table 4.

\begin{tabular}{clcccc} 
City & $\begin{array}{c}\text { Spatial } \\
\text { Adjusted } \\
\text { Liveability } \\
\text { Index }\end{array}$ & $\begin{array}{c}\text { RANK - } \\
\text { Spatial } \\
\text { Adjusted } \\
\text { Liveability } \\
\text { Index }\end{array}$ & $\begin{array}{c}\text { EIU } \\
\text { Liveability } \\
\text { Index (From } \\
\text { City Sample } \\
\text { Used) }\end{array}$ & $\begin{array}{c}\text { Change in } \\
\text { Rank }\end{array}$ \\
\hline 1 & Hong Kong & 87.8 & 1 & 10 & 9 \\
\hline 2 & Amsterdam & 87.4 & 2 & 8 & 6 \\
\hline 3 & Osaka & 87.4 & 3 & 3 & 0 \\
\hline 4 & Paris & 87.1 & 4 & 5 & 1 \\
\hline 5 & Sydney & 86.0 & 5 & 2 & -3 \\
\hline 6 & Stockholm & 86.0 & 6 & 4 & -2 \\
\hline 7 & Berlin & 85.9 & 7 & 7 & 0 \\
\hline 8 & Toronto & 85.4 & 8 & 1 & -7
\end{tabular}

\footnotetext{
${ }^{4}$ Frank, K. (2011), The Wealth Report: A Global Perspective on Prime Property and Wealth. Available at: http://www.knightfrank.com/wealthreport/2011/images/brochure.pdf [12.05.2017].
} 


\begin{tabular}{rlcccc}
9 & Munich & 85.1 & 9 & 9 & 0 \\
\hline 10 & Tokyo & 84.4 & 10 & 6 & -4 \\
\hline & Table 4: & Best Cities Ranking (EIU) at a Global Level in 2016
\end{tabular}

Table 4: Best Cities Ranking (EIU) at a Global Level in 2016

Source: A special report from the Economist Intelligence Unit Global Cities Index and Global Cities Outlook, 2016

\subsection{The Mercer Index}

The Quality of Life Index, proposed by MERCER, is known as The MERCER Index. The Mercer Index is calculated based on 39 factors grouped into ten categories, which contain all the key elements that can be used to describe the quality of life with respect to 450 cities. The calculation methodology for the Mercer Index is based on the following elements:

- To determine the tangible values of qualitative perception with regard to the assessed objectives;

- To select the factors which represent the criteria considered to be the most relevant;

- To establish the differences in terms of the quality of life among the cities subject to analysis;

- To calculate the Index on a City-by-City basis (one-to-one comparison), in order to provide a synthesis of the differences between two such cities;

- To determine the Quality of Life Index for cities.

The Mercer Index is based on the following categories of indicators: consumer goods, economic environment, housing, medical and health considerations, natural environment, political and social environment, public services and transport, recreation, schools and education and socio-cultural environment.

In 2016, the city ranking based on the Mercer Index values is as follows: 1 - Vienna (Austria), 2 - Zurich (Switzerland), 3 - Auckland (New Zealand), 4 - Munich (Germany), 5 - Vancouver (Canada), 6 - Dusseldorf (Germany), 7 - Frankfurt (Germany), 8 - Geneva (Switzerland), 9 - Copenhagen (Denmark) and 10 - Basel (Switzerland).

\section{BUCHAREST - THE MOST LIVEABLE CITY IN ROMANIA}

The Capital City Romania, Bucharest, is currently considered as the most liveable city in the country, followed by Cluj-Napoca, Timișoara, Brașov, Constanța and Sibiu.

Even though Bucharest is not listed in any of the above-mentioned rankings, it is one of the most attractive cities in Romania, due to its location in the Bucharest Ilfov region, one of the most important EU-28 regions. In this region, the GDP value per inhabitant amounted to EUR 35,500 in 2014 , being ranked the $40^{\text {th }}$ out of the $276 \mathrm{EU}$ regions (in the first 15\%) (cf. Figure 2). 


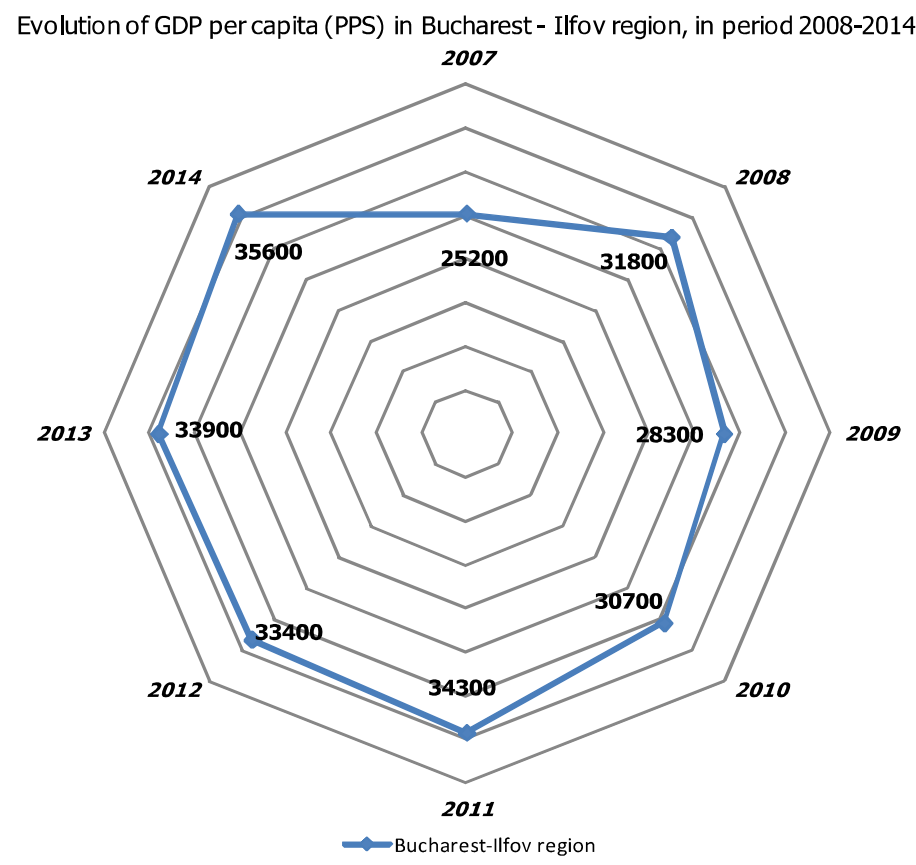

Figure 2: Evolution of GDP per capita (PPS) in Bucharest Ilfov region for the Period 2007-2014

Source: Author computations.

Meanwhile, evolution permanent resident population decreased by about $-2.38 \%$ in 2016 comparatively 2012, and for usual resident population with $-2.25 \%$ for the same period (cf. Figure 3). This trend is an obviously process of urbanisation of the capital city.

Demographic evolution in Bucharest Municipality, 2012-2016 (no.)

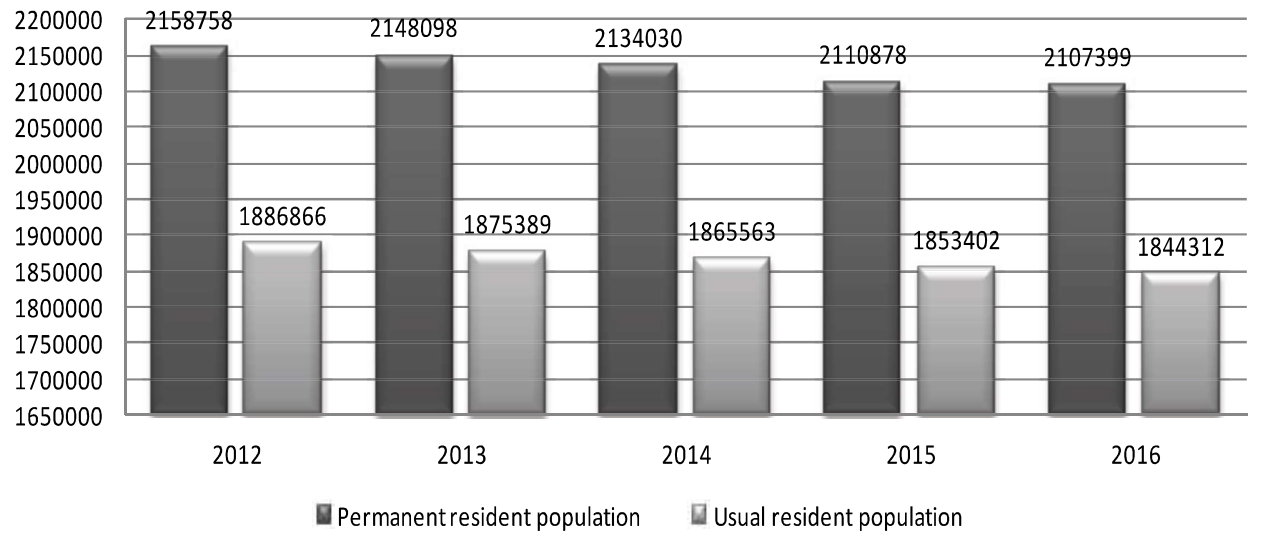

Figure 3: Demographic evolution in Bucharest between 2012 and 2016

Source: http://statistici.insse.ro/shop/index.jsp?page=tempo3\&lang=ro\&ind=POP105A [12.05.2017].

If the GDP value per inhabitant provides a certain comfort for Bucharest inhabitants, from an economic perspective, in terms of the quality of life, there are certain 
shortcomings, which need time to be remedied and which affect the liveability level of this city.

In order to provide an assessment of how liveable Bucharest is, below are given the results of a Report elaborated by the European Commission in 2015 under the title 'Quality of life in European Cities', and which concerns 83 EU cities, the criteria underlying such analysis being given in Table 5 .

\begin{tabular}{|c|c|c|c|}
\hline $\begin{array}{l}\text { Satisfaction with } \\
\text { Infrastructure } \\
\text { and Facilities of } \\
\text { The City }\end{array}$ & $\begin{array}{l}\text { People's Views } \\
\text { About Their } \\
\text { City }\end{array}$ & $\begin{array}{l}\text { People's } \\
\text { Satisfaction with } \\
\text { Their City in } \\
\text { Relation with Its } \\
\text { Environment }\end{array}$ & $\begin{array}{l}\text { People's } \\
\text { Satisfaction with } \\
\text { Their Personal } \\
\text { Situation }\end{array}$ \\
\hline $\begin{array}{l}\text { Public transport; } \\
\text { Health care services; } \\
\text { Sports facilities; } \\
\text { Cultural facilities; } \\
\text { Educational facilities; } \\
\text { Streets and } \\
\text { buildings; } \\
\text { Public spaces; } \\
\text { Availability of retail } \\
\text { stores. }\end{array}$ & $\begin{array}{l}\text { Employment } \\
\text { opportunities; } \\
\text { The housing } \\
\text { situation; } \\
\text { The presence and } \\
\text { integration of } \\
\text { foreigners; } \\
\text { Safety and trust; } \\
\text { City } \\
\text { administrative } \\
\text { services. }\end{array}$ & $\begin{array}{l}\text { Air quality; } \\
\text { Noise level; } \\
\text { Cleanliness; } \\
\text { Green spaces; } \\
\text { Fight against climate } \\
\text { change. }\end{array}$ & $\begin{array}{l}\text { Life in general; } \\
\text { Place where } \\
\text { people live; } \\
\text { Financial situation } \\
\text { of household; } \\
\text { Personal job } \\
\text { situation. }\end{array}$ \\
\hline
\end{tabular}

Table 5: The Main Criteria for the Evaluation of People's Satisfaction in European Cities

Source: Quality of life in European Cities, 2015, European Commission.

With respect to the quality of life in Bucharest and the liveability level of this city, the answers provided by its inhabitants (in 2015) are synthesised below:

1. Regarding the overall level of satisfaction of the Bucharest inhabitants, around $80 \%$ expressed their satisfaction with their life in this city. The most satisfied inhabitants are those who live in Zurich (99\%), Aalborg, Vilnius and Belfast (each with 98\%), while the most dissatisfied ones live in Athens (67\%) and in Naples (75\%);

2. Regarding the quality of public transportation, only $48 \%$ of the Bucharest inhabitants declared their satisfaction with it. In Europe, the most satisfied inhabitants live in Zurich (97\%), Vienna (95\%) and Helsinki $(93 \%)$, while at the other end there are the inhabitants of Naples (33\%), Rome (30\%) and Palermo (14\%);

3. Regarding the public healthcare services, less than half of the Bucharest inhabitants are dissatisfied with them, in comparison with $90 \%$ of the inhabitants of Zurich, Groningen, Antwerp, Graz, Lille, Amsterdam, Bordeaux, Strasbourg, Geneva and Liège;

4. The level of satisfaction of inhabitants with respect to the education sector in Bucharest is 48\%, the lowest in Europe (after the inhabitants of Sofia, with 47\%). The first ranks are occupied by the inhabitants of Groningen, Rennes (both with 88\%), Prague (87\%), Antwerp (86\%) and Zurich (85\%); 
5. The condition of buildings - less than $50 \%$ of the respondents are satisfied with it. The most satisfied ones live in Zurich (93\%) and in Stockholm (90\%);

6. The level of satisfaction regarding the degree of cleanliness in Bucharest is very small (only $37 \%$ ), and the remaining $62 \%$ of inhabitants are totally dissatisfied with this aspect; in the European Union, $95 \%$ of the citizens of Luxemburg are satisfied with the degree of cleanliness of their city, and $90 \%$ of the inhabitants of Vienna;

7. The level of noise is also disturbing for the inhabitants of Bucharest, $69 \%$ being completely dissatisfied with this aspect;

8. The quality of air can be an important criterion for determining a liveable city. $78 \%$ of the inhabitants of Bucharest are dissatisfied with this aspect. In Vienna, Helsinki and Dublin, $88 \%$ of the inhabitants are dissatisfied with the quality of air in their cities;

9. $42 \%$ of the inhabitants of Bucharest are satisfied with the public administration of their city, in comparison with Zurich (90\%), Luxembourg (87\%), Graz (83\%) and Oslo (80\%). Also, $45 \%$ of the inhabitants of Bucharest believe that the public administration of their city is efficient, while the other $55 \%$ consider it is inefficient;

10. With respect to safety, only $18 \%$ of the inhabitants of Bucharest feel safe in their city;

11. The difficulty of finding a workplace is a criterion which, for most of the inhabitants, represents an essential condition for surviving in a city like Bucharest. Around $48 \%$ of the respondents consider that finding a workplace in Bucharest is easy;

12. The financial satisfaction of the inhabitants of European cities varies a lot from one city to another. In Bucharest, $9 \%$ of the inhabitants are satisfied with this aspect, and approximately $55 \%$ are relatively satisfied. The level of financial satisfaction is maximum in Zurich (92\%) and minimum in Athens (33\%).

Given the above-mentioned statistics, one can conclude that, even though the level of development of Bucharest is superior to that of other cities in Romania, the degree of satisfaction of the inhabitants of this city is relatively low. Even if the overall level of satisfaction is $80 \%$ among its inhabitants, the other problems (low quality public healthcare services, high degree of air pollution, infrastructure, education system which needs improvement), endanger the liveability feature of this city, and intense efforts are necessary to remedy such problems.

In terms of the overall perception dynamics, the level of satisfaction with respect to life in Bucharest decreased in 2015, in comparison with 2013, from $83 \%$ to $80 \%$, which shows a negative trend pertaining to the quality of life in the Capital City of Romania. 


\section{CONCLUSIONS}

The purpose of this article is to provide an overall image of what liveable cities are. Starting from the theoretical aspects presented in the first part of this work, and ending up with the practical ones, an attempt was made to provide an answer to the following question: why are some cities more attractive than others and what criteria should be fulfilled for the life of a city's inhabitants to be considered qualitative, and that city to be deemed liveable. For a city to be liveable, it is bound to fulfil several conditions, the most important ones being related to economy, environment, infrastructure (healthcare, transport, education, etc.), and also to aesthetics and culture. The economic aspects are not always revealing for the liveability level, unless they are accompanied by positive effects on the overall quality of life.

Albeit there is no generally accepted concept of Liveability Index, one can ascertain that the cities ranked on the first positions worldwide are found in most methodologies identified in this study. Hence, the city of Tokyo can be found in five out of six categories (methodologies) proposed by international organisations, along with the City of London (in four out of six categories) and with New York City (in four out of six categories) (cf. Table 7).

\begin{tabular}{|c|c|c|c|c|c|c|}
\hline & Economy & R\&D & GCI & GCO & $\begin{array}{l}\text { Spatial } \\
\text { Adjusted } \\
\text { Liveability } \\
\text { Index }\end{array}$ & $\begin{array}{l}\text { EIU } \\
\text { Liveability } \\
\text { index }\end{array}$ \\
\hline 1. & Tokyo & New York & London & $\begin{array}{l}\text { San } \\
\text { Francisco }\end{array}$ & Hong Kong & Toronto \\
\hline 2. & London & Tokyo & New York & New York & $\begin{array}{l}\text { Amsterda } \\
\mathrm{m}\end{array}$ & Sydney \\
\hline 3. & New York & London & Paris & Boston & Osaka & Osaka \\
\hline 4. & Beijing & Los Angeles & Tokyo & London & Paris & Stockholm \\
\hline 5. & Hong Kong & Seoul & $\begin{array}{l}\text { Hong } \\
\text { Kong }\end{array}$ & Huston & Sydney & Paris \\
\hline 6. & Singapore & Boston & $\begin{array}{l}\text { Los } \\
\text { Angeles }\end{array}$ & Atlanta & Stockholm & Tokyo \\
\hline 7. & Shanghai & Singapore & Chicago & Stockholm & Berlin & Berlin \\
\hline 8. & Zurich & Paris & Singapore & $\begin{array}{l}\text { Amsterda } \\
\mathrm{m}\end{array}$ & Toronto & $\begin{array}{l}\text { Amsterda } \\
\mathrm{m}\end{array}$ \\
\hline 9. & Seoul & $\begin{array}{l}\text { San } \\
\text { Francisco }\end{array}$ & Beijing & Munich & Munich & Munich \\
\hline 10. & Sydney & Chicago & $\begin{array}{l}\text { Washingt } \\
\text { on DC }\end{array}$ & Zurich & Tokyo & Hong Kong \\
\hline
\end{tabular}

Table 7: Global Cities Ranking regarding to different Liveability Indices, 2016

Source: Author computations.

In Romania, the cities that might be classified as liveable are: Bucharest, ClujNapoca, Timișoara, Brașov, Constanța and Sibiu. The Capital City of Romania, i.e. Bucharest, is ranked the $28^{\text {th }}$ in a List of European Capital Cities, being outranked by Cities like Sofia, Lisbon or Budapest, which means it still does not fulfil many of the criteria for a liveable city. 


\section{REFERENCES}

[1] Alberti, M. (2000), Urban Form and Ecosystem Dynamics: Empirical Evidence and Practical Implications, in William, K., Burton, E., Jenks, M. (Eds.), Achieving Sustainable Urban Form. E. \& F.N. Spon, London, pp. 84-96.

[2] Berta, N., (2008), Le concept d'externalité de l'économie externe à «l'interaction directe»: Quelques problèmes de définition. Documents de travail du Centre d'Economie de la Sorbonne. Available at: https://halshs.archives-ouvertes.fr/halshs00270672/document [12.05.2017].

[3] Bohm, P. (1987), External Economies, in The New Palgrave: A Dictionary of Economics, Macmillan and Stockton, London and New York, pp. 261-263.

[4] Buchanan, J. M. (1966), "Joint Supply, Externality and Optimality", Economica, 33, 132, pp. 404-415.

[5] Buchanan, J. M., Stubblebine, W. C. (1962), "Externality", Economica, 29, 116, pp. 371-384.

[6] Florida, R. (2002), "The Cities and Creative Class, City and Community", 2, 1, pp. 3-19. Available at:

http://creativeclass.com/rfcgdb/articles/4\%20Cities\%20and\%20the\%20Creative\% 20Class.pdf [12.05.2017].

[7] Frank, K. (2011), The Wealth Report: A Global Perspective on Prime Property and Wealth. Available at:

http://www.knightfrank.com/wealthreport/2011/images/brochure.pdf [12.05.2017].

[8] Glaeser, E. (2011), Triumph of the City: How Our Greatest Invention Makes Us Richer, Smarter, Penguin, New York (NY).

[9] Girardet, H. (2004), Cities People Planet: Liveable Cities for a Sustainable World. Wiley-Academy, Hoboken (NJ).

[10] Jacobs, J. (1969), The economy of Cities, Random House, New York (NY).

[11] Kearney, A. T. (2010), The Urban Elite: The A.T. Kearney Global Cities Index 2010. Available at: http://www.atkearney.com/images/global/pdf/Urban_EliteGCI_2010.pdf [12.05.2017].

[12] Ley, A., Newton, P. (2010), Creating and Sustaining Liveable Cities, in Kallidaikurichi, S., Yuen, B. (Eds.), Developing Living Cities. From Analysis to Action, World Scientific Publishing, Singapore, pp. 191-229.

[13] Luque-Martinez, T., Munoz-Leiva, F. (2005) "City Benchmarking: A Methodological Proposal Referring Specifically to Granada", Cities, 22, 6, pp. 411423.

[14] Lyndhurst, B. (2004), Liveability \& Sustainable Development: Bad Habits \& Hard Choices, July, Final Report for the UK Office of the Deputy Prime Minister.

[15] Nijkamp, P., Verhoef, E., Externalities in the Urban Economy. Available at: https://papers.tinbergen.nl/03078.pdf [12.05.2017].

[16] Remy J., (2015), L'espace, un objet central de la sociologie, Erès, Toulouse. 
[17] Kallidaikurichi, S., Yuen, B. (Eds.), Developing Living Cities. From Analysis to Action, World Scientific Publishing, Singapore.

[18] AARP Public Policy Institute (2005), Liveable Communities: An Evaluation Guide. Report available at: https://assets.aarp.org/rgcenter/il/d18311_communities.pdf [12.05.2017].

[19] https://www.cardiffpartnership.co.uk/wp-content/uploads/ITEM-4-APP-ADraft-Liveable-City-Report-2017.pdf [12.05.2017].

[20] European Commission, Quality of Life in European Cities 2015, Flash Eurobarometer 419. Available at: http://ec.europa.eu/regional_policy/sources/docgener/studies/pdf/urban/survey20 15_en.pdf [12.05.2017].

[21] https://www.imercer.com/content/mobility/rankings/d147852/index.html [12.05.2017].

[22] AT Kearney (2016), Global Cities 2016. Report available at: https://www.atkearney.com/documents/10192/8178456/Global+Cities+2016.pdf/8 139cd44-c760-4a93-ad7d-11c5d347451a [12.05.2017].

[23] http://statistici.insse.ro/shop/ [12.05.2017].

Article distributed under a Creative Commons AttributionNonCommercial-NoDerivatives 4.0 International License (CC BY-NC-ND).

Received September 23, 2016

Accepted October 12, 2016 